\title{
Patterns of Internet Use among Students Universiti Teknologi Malaysia: Kolej Perdana Case Study
}

\author{
Mohd Murtadha Mohamad ${ }^{1, *}$ Nurriza Ab Latif ${ }^{2}$ Sharifah Nurarfah S. Abd Rahman ${ }^{3}$ \\ Mohd Fahmi Muhammad Mubarak ${ }^{2}$ Syamsul Hendra Mahmud ${ }^{4}$ Mohd Fadthul Ikmal \\ Misnal $^{5}$ Md Yani Kasiren ${ }^{6}$ Nur Zulyiana Zulkapli ${ }^{7}$ Siti Zhahara Salleh ${ }^{8}$ \\ ${ }^{1}$ School of Computing, Faculty of Engineering, Universiti Teknologi Malaysia, 81310 UTM Johor Bahru, Johor \\ ${ }^{2}$ Department of Biosciences, Faculty of Science, Universiti Teknologi Malaysia, 81310 UTM Johor Bahru, Johor \\ ${ }^{3}$ School of Education, Faculty of Social Sciences and Humanities, Universiti Teknologi Malaysia, 81310 UTM Johor \\ Bahru, Johor \\ ${ }^{4}$ Faculty of Built Environment and Surveying, Universiti Teknologi Malaysia, 81310 UTM Johor Bahru, Johor. \\ ${ }^{5}$ School of Mechanical Engineering, Faculty of Engineering, Universiti Teknologi Malaysia, 81310 UTM Johor Bahru, \\ Johor \\ ${ }^{6}$ Centre for Community and Industry Network, Office of the Deputy Vice Chancellor (Research \& Innovation), Universiti \\ Teknologi Malaysia, 81310 Johor Bahru, Johor \\ ${ }^{7}$ School of Human Resource, Development and Psychology, Faculty of Social Science and Humanities, Universiti \\ Teknologi Malaysia, 81310 UTM Johor Bahru, Johor \\ ${ }^{8}$ Pusat Pengurusan Makmal Universiti, Blok T03 Bangunan UIRL, Universiti Teknologi Malaysia, 81310 Johor Bahru, \\ Johor \\ *Corresponding author. Email: murtadha@utm.my
}

\begin{abstract}
The Internet usage has become prevalent phenomenon among university students. Researchers claim that highly usage of the Internet affected the student's academic performance. This study aims to determine the Internet use patterns and the relationship between Internet usage and examination results among Universiti Teknologi Malaysia students. A total of 130 questionnaires were distributed using simple random sampling among undergraduate Kolej Perdana, Universiti Teknologi Malaysia students who were willing to participate. Data collected were analysed using descriptive statistics and Spearman's rho test, a non-parametric test. The finding reveals that internet usage among UTM students were very high and weak correlation was considered between internet use patterns and examination results, $\mathrm{r}(130)=0.116$ with $\mathrm{p}$ value $>0.05$
\end{abstract}

Keywords: Internet; university students, examination

\section{INTRODUCTION}

The Internet is no longer merely an infrastructure; it has become an unlimited space for the exchange of information, social networking and cyber behaviour [1]. The Internet today is a worldwide phenomenon whose existence cannot be easily or clearly described, according to [2]. To summarise, the Internet is a large computer network that connects millions of smaller computers for thousands of business, state, science, academic and other organisations at numerous sites in different countries [3]. The users can access to a large pool of information sources of Internet with fast, user-friendly and unlimited access with less time and cost [4]. Based on statistics of Internet users, there has been a tremendously high penetration rate of Internet population globally from 2011 to May 2015; 20 million to 3 billion of Internet users accounted for [4].

University students are classified as the largest and the most frequent users of Internet-based technology, which accounted for $88 \%$ compared to other groups. This group of users is also known as the digital natives as they have been growing up with the digital technologies throughout their life. Moreover, with the advanced development of network facilities in universities which emphasises on learning, entertainment and research, all these contributions have led to the increase of Internet usage among university students [5].

University students are regarded as a crucial asset for a nation in building and developing its prosperity and growth in the future. Thus, the development of the university 
students that are capable to strive are decisive so that they can contribute productively to the nation. As such, they can become addicted to Internet if no precautionary actions are taken to avoid them from becoming addicted $[6,7]$

In Malaysia, the percentage of individuals age 15 and above using Internet was $81.2 \%$ incremented by $1.1 \%$ compared to the previous year in 2017 [8]. Within this volume, $96.5 \%$ user has been participating in social networks with a significant increment of $10.2 \%$. In 2018, according to [9], the number of enrolled students in Malaysian Public University is 552,702 where 31,992 are belong to Universiti Teknologi Malaysia.

Although there are many benefits linked with the Internet use, many studies have shown that students become addicted to the Internet which eventually caused to academic failure [10]. To relate the given facts as well as growing concern on the risk associated with Internet use, this paper is aiming to study the relation of Internet use patterns and relationship between internet use and examination results. The sample of case study is the students of Kolej Perdana Universiti Teknologi Malaysia.

\section{LITERATURE REVIEW}

As borderless connection, people have been using Internet all over the world for so many purposes including entertainment, social interaction, education, and commerce. Higher education is one of the areas that experienced the inevitable changes under the growing use of the Internet. [11] stated that university students are among the largest and the most frequent users of the Internet. Students in universities use the Internet as a platform for entertainment and socialization while educators on the other hand, use the Internet to engage students in the process of creating and sharing knowledge and in more efficient ways of communication [12]. Hence, Internet is no longer used for leisure but has become platforms for interaction and engaging with learners in higher education.

Jacobsen and Forste clarified about the impact of electronic media use on the scholastic and public activities of college understudies. Using time-diary and survey data, the utilization of different kinds of electronic media among first-year students were investigated. Time-diary results propose that most students utilize electronic media to perform various tasks. Vigorous relapse results show a negative connection between the utilization of different sorts of electronic media and first-semester grades. Also, a positive relationship between long range informal communication site use, wireless correspondence, face-toface social collaboration were found [13].

Ref [14] analyses revealed that residential status of students does not reflect on the amount of time spent for the use of Internet. Based on the study, it was reported that students staying on campus were found to use the Internet more than students staying off campus and perform significantly worse academically than those staying off campus. In addition, ref [15] study found that a student's academic achievement can be increased if they allocate how to use the Internet in the appropriate way. Furthermore, if the students are using online media productively they will definitely increase academic achievement.

\section{METHODOLOGY}

A survey $(n=130)$ was distributed to one of ten residential colleges in Universiti Teknologi Malaysia. The selected college was Kolej Perdana which its capacity of resident is 840 students. The target study population was undergraduate students who used the Internet provided by the university or by their own telco subscription.

\section{RESULTS AND FINDINGS}

The section below is the presentation and analysis of data from the responses obtained from the distributed questionnaires. The results were based on the various data obtained from the use of questionnaires.

Table 1 Distribution of Respondents according to Gender

\begin{tabular}{|c|c|c|}
\hline & Frequency & Percentage (\%) \\
\hline Male & 46 & 35.4 \\
\hline Female & 84 & 64.6 \\
\hline Total & $\mathbf{1 3 0}$ & $\mathbf{1 0 0}$ \\
\hline
\end{tabular}

\subsection{The Pattern of Social Media Use among UTM Students}

Based on Table 2, the study found that $71.5 \%$ of students often stay on the Internet longer than they intended (Item A1). Meanwhile, $58.4 \%$ of students always saying "just a few more minutes" when using the Internet (Item A16). However, there are $80.7 \%$ of students were failed to cut off time spent on social media (Item A17), while $69.2 \%$ of students fear that life without the internet would be boring, empty and joyless (Item A12). This proves that social media use among UTM students is very high.

Besides that, the findings also show that $63.9 \%$ of students say that people rarely comment when he/she spend so much time on the Internet (Item A5). However, $46.2 \%$ of students state the amount of time he/she spends on social media rarely affects their grades (Item A6) and $44.6 \%$ of students state usage of Internet rarely affects their job performance or productivity (Item A8). Next, $43 \%$ of students state rarely lose sleep due to late night log-ins (Item A14). These findings show that Internet use does not affect students' routines but it does give benefit to them. 
Table 2 Distribution of Respondents towards Internet Use Patterns

\begin{tabular}{|c|c|c|c|c|c|c|}
\hline Item & Never & Rarely & Sometimes & Often & Always & Mean \\
\hline A1. & $\begin{array}{l}0 \\
0\end{array}$ & $\begin{array}{c}8 \\
6.2\end{array}$ & $\begin{array}{c}29 \\
22.3\end{array}$ & $\begin{array}{c}57 \\
43.8\end{array}$ & $\begin{array}{c}36 \\
27.7\end{array}$ & 3.93 \\
\hline A2. & $\begin{array}{c}9 \\
6.9\end{array}$ & $\begin{array}{c}25 \\
19.2\end{array}$ & $\begin{array}{c}69 \\
53.1\end{array}$ & $\begin{array}{c}22 \\
16.9\end{array}$ & $\begin{array}{c}5 \\
3.8\end{array}$ & 2.92 \\
\hline A3. & $\begin{array}{l}26 \\
20\end{array}$ & $\begin{array}{c}32 \\
24.6\end{array}$ & $\begin{array}{c}42 \\
32.3\end{array}$ & $\begin{array}{c}20 \\
15.4\end{array}$ & $\begin{array}{c}10 \\
7.7\end{array}$ & 2.66 \\
\hline A4. & $\begin{array}{c}29 \\
22.3\end{array}$ & $\begin{array}{c}36 \\
27.7\end{array}$ & $\begin{array}{c}32 \\
24.6\end{array}$ & $\begin{array}{c}26 \\
20.0\end{array}$ & $\begin{array}{c}7 \\
5.4\end{array}$ & 2.58 \\
\hline A5. & $\begin{array}{c}37 \\
28.5\end{array}$ & $\begin{array}{c}46 \\
35.4\end{array}$ & $\begin{array}{c}27 \\
20.8\end{array}$ & $\begin{array}{c}17 \\
13.1\end{array}$ & $\begin{array}{c}3 \\
2.3\end{array}$ & 2.25 \\
\hline A6. & $\begin{array}{c}24 \\
18.5\end{array}$ & $\begin{array}{c}36 \\
27.7\end{array}$ & $\begin{array}{c}42 \\
32.3\end{array}$ & $\begin{array}{c}19 \\
14.6\end{array}$ & $\begin{array}{c}9 \\
6.9\end{array}$ & 2.64 \\
\hline A7. & $\begin{array}{c}14 \\
10.8\end{array}$ & $\begin{array}{c}32 \\
24.6\end{array}$ & $\begin{array}{c}43 \\
33.1\end{array}$ & $\begin{array}{c}23 \\
17.7\end{array}$ & $\begin{array}{c}18 \\
13.8\end{array}$ & 2.99 \\
\hline A8. & $\begin{array}{c}20 \\
15.4\end{array}$ & $\begin{array}{c}38 \\
29.2\end{array}$ & $\begin{array}{c}43 \\
33.1\end{array}$ & $\begin{array}{c}23 \\
17.7\end{array}$ & $\begin{array}{c}6 \\
4.6\end{array}$ & 2.67 \\
\hline A9. & $\begin{array}{c}20 \\
15.4\end{array}$ & $\begin{array}{c}36 \\
27.7\end{array}$ & $\begin{array}{c}44 \\
33.8\end{array}$ & $\begin{array}{c}23 \\
17.7\end{array}$ & $\begin{array}{c}7 \\
5.4\end{array}$ & 2.70 \\
\hline A10. & $\begin{array}{c}12 \\
9.2\end{array}$ & $\begin{array}{c}29 \\
22.3\end{array}$ & $\begin{array}{c}49 \\
37.7\end{array}$ & $\begin{array}{c}32 \\
24.6\end{array}$ & $\begin{array}{c}8 \\
6.2\end{array}$ & 2.96 \\
\hline A11. & $\begin{array}{c}11 \\
8.5\end{array}$ & $\begin{array}{c}27 \\
20.8\end{array}$ & $\begin{array}{c}58 \\
44.6\end{array}$ & $\begin{array}{c}28 \\
21.5\end{array}$ & $\begin{array}{c}6 \\
4.6\end{array}$ & 2.93 \\
\hline A12. & $\begin{array}{c}15 \\
11.5\end{array}$ & $\begin{array}{c}25 \\
19.2\end{array}$ & $\begin{array}{c}41 \\
31.5\end{array}$ & $\begin{array}{c}28 \\
21.5\end{array}$ & $\begin{array}{c}21 \\
16.2\end{array}$ & 3.12 \\
\hline A13. & $\begin{array}{c}48 \\
36.9\end{array}$ & $\begin{array}{c}35 \\
26.9\end{array}$ & $\begin{array}{c}33 \\
25.4\end{array}$ & $\begin{array}{c}12 \\
9.2\end{array}$ & $\begin{array}{c}2 \\
1.5\end{array}$ & 2.12 \\
\hline A14. & $\begin{array}{c}25 \\
19.2\end{array}$ & $\begin{array}{c}31 \\
23.8\end{array}$ & $\begin{array}{c}35 \\
26.9\end{array}$ & $\begin{array}{c}25 \\
19.2\end{array}$ & $\begin{array}{c}14 \\
10.8\end{array}$ & 2.78 \\
\hline
\end{tabular}




\begin{tabular}{|c|c|c|c|c|c|c|}
\hline A15. & $\begin{array}{c}26 \\
20.0\end{array}$ & $\begin{array}{c}22 \\
16.9\end{array}$ & $\begin{array}{c}54 \\
41.5\end{array}$ & $\begin{array}{c}21 \\
16.2\end{array}$ & $\begin{array}{c}7 \\
5.4\end{array}$ & 2.70 \\
\hline A16. & $\begin{array}{c}7 \\
5.4\end{array}$ & $\begin{array}{c}10 \\
7.7\end{array}$ & $\begin{array}{c}37 \\
28.5\end{array}$ & $\begin{array}{c}48 \\
36.9\end{array}$ & $\begin{array}{c}28 \\
21.5\end{array}$ & 3.62 \\
\hline A17. & $\begin{array}{l}10 \\
7.7\end{array}$ & $\begin{array}{c}15 \\
11.5\end{array}$ & $\begin{array}{c}51 \\
39.2\end{array}$ & $\begin{array}{c}38 \\
29.2\end{array}$ & $\begin{array}{c}16 \\
12.3\end{array}$ & 3.27 \\
\hline A18. & $\begin{array}{c}18 \\
13.8\end{array}$ & $\begin{array}{c}32 \\
24.6\end{array}$ & $\begin{array}{c}54 \\
41.5\end{array}$ & $\begin{array}{c}13 \\
10.0\end{array}$ & $\begin{array}{c}13 \\
10.0\end{array}$ & 2.78 \\
\hline A19. & $\begin{array}{c}31 \\
23.8\end{array}$ & $\begin{array}{c}30 \\
23.1\end{array}$ & $\begin{array}{c}42 \\
32.3\end{array}$ & $\begin{array}{c}22 \\
16.9\end{array}$ & $\begin{array}{c}5 \\
3.8\end{array}$ & 2.54 \\
\hline A20. & $\begin{array}{c}41 \\
31.5\end{array}$ & $\begin{array}{c}31 \\
23.8\end{array}$ & $\begin{array}{c}37 \\
28.5\end{array}$ & $\begin{array}{c}12 \\
9.2\end{array}$ & $\begin{array}{c}9 \\
6.9\end{array}$ & 2.36 \\
\hline
\end{tabular}

\subsection{The Relationship between Internet Use Patterns and Examination Result}

among UTM students, $\mathrm{r}(130)=.116, \mathrm{p}>.05$. It explains that the Internet use patterns are not related to excellent examination results.

Table 3 indicated that there was no significant correlation between Internet use patterns and academic achievement

Table 3 Spearman's rho Test for Examination Result and Internet Use Patterns

\begin{tabular}{|l|l|l|r|r|}
\hline & & & \multicolumn{1}{|c|}{ CGPA } & \multicolumn{1}{c|}{ SumInternetUse } \\
\hline $\begin{array}{l}\text { Spearman's } \\
\text { rho }\end{array}$ & CGPA & Correlation Coefficient & 1.000 & .116 \\
\hline & & Sig. (2-tailed) & - & .188 \\
\hline & & $\mathrm{N}$ & 130 & 130 \\
\hline & $\begin{array}{l}\text { SumInter } \\
\text { netUse }\end{array}$ & Correlation Coefficient & .116 & 1.000 \\
\hline & & Sig. (2-tailed) & .188 & 130 \\
\hline & & $\mathrm{N}$ & 130 & \\
\hline
\end{tabular}

\section{CONCLUSION}

Conclusively, our study revealed that patterns of Internet used has no significant impact on the examination results of students of Kolej Perdana UTM. Even though $71.5 \%$ of the students agreed that they often stay on the Internet longer than they intended, no negative correlation in the academic achievement of the students was observed. Further study is suggested with wider instruments and larger sample size in order to increase the validity of the study

\section{REFERENCES}

[1] K.K. Mak, C.M. Lai, H. Watanabe, D.I. Kim, N. Bahar, M. Ramos, K.S. Young, R.C. Ho, N.R. Aum, \& C. Cheng. Epidemiology of Internet Behaviors and Addiction Among Adolescents in Six Asian Countries. Cyberpsychology, Behavior, and Social Networking, 17(11), 2014, pp. 720-728. 
[2] U.J. Emeka, \& O.S. Nyeche. Impact of Internet Usage on the Academic Performance of Undergraduates Students: A Case Study of the University of Abuja, Nigeria. International Journal of Scientific \& Engineering Research, 7(10), 2016, pp. 1018-1029.

[3] M.A. Jibrin, M.N. Musa, \& T. Shittu. Effects of Internet on the Academic Performance of Tertiary Institutions' Students in Niger State, Nigeria. International Journal of Education, Learning and Training, 2(2), 2017, pp. 57-69.

[4] K. Norliah, S. Safiah, I. Zakiah, K. Massila, A.H. Mahadi, \& M. Shahrulanuar. Internet Usage Pattern and Types of Internet Users Among Malaysian University Students. Journal of Engineering and Applied Sciences, 12(6), 2017, pp. 1433-1439.

[5] E. Anwar. Internet Addiction Among Secondary School Children and Its Relation with Their Academic Achievements. PERIPEX-Indian Journal of Research, 3(12), 2014, pp. 72-74.

[6] S.R. Adekunmisi, E.B. Ajala, \& A.O. Iyoro. Internet Access and Usage by Undergraduate Students: A Case Study of Olabisi Onabanjo University, Nigeria. Library Philosophy \& Practice, 2013.

[7] B. Kayastha, A. Gurung, \& R. Chawal. A Descriptive Study to Assess the Level of Internet Addiction Among Adolescents: A Case Study of High Schools in Mangalore. Journal of Child and Adolescent Behavior, 6(378), 2018, p.2.

[8] Department of Statistics Malaysia. ICT Use and Access by Individuals and Households Survey Report, Malaysia, 2018 [Press release]. 2019, Retrieved from https://www.dosm.gov.my/v1/index.php?r=column/pdf Prev\&id=U3VCWU95MFNZK2kxbHd6cnBYZDY5dz 09

[9] Quick Fact 2019 Malaysia Educational Statistic. Putrajaya, Educational Data Sector Educational Planning and Research Division Ministry of Education Malaysia.

[10] H.H. Siraj, A. Salam, N.A. Hassan, T.H. Jin, R. Roslan, \& M.N. Othman. Internet Usage and Academic Performance: A Study in a Malaysian Public University. International Medical Journal, 22(2), 2015, pp. 83-86

[11] N. Kudus, S. Sidek, Z. Izharrudin, M. Kamalrudin, M. Abu Hassan, \& S. Mohamed. Internet Usage Pattern and Types of Internet Users among Malaysian
University Students. Journal of Engineering and Applied Sciences, 12(6), 2017, pp.1433-1439

[12] Y. Aleksandrova, \& S. Parusheva. Social Media Usage Patterns in Higher Education Institutions - An Empirical Study. International Journal of Emerging Technologies in Learning (IJET), 14(5), 2019, pp. 108121.

[13] W. Jacobsen, \& R. Forste. The Wired Generation: Academic and Social Outcomes of Electronic Media Use Among University Students. Cyberpsychology, Behavior and Social Networking, 14(5), 2011, pp. 275280.

[14] U.T. Ngoumandjoka. Correlation between Internet usage and academic performance among university students (Unpublished master's dissertation). University of the Witwatersrand, Johannesburg, South Africa. 2013.

[15] M.S. Shahibi, \& K.K.K. Ku Rusli. The Influence of Internet Usage on Student's Academic Performance, International Journal of Academic Research in Business and Social Sciences, Human Resource Management Academic Research Society, International Journal of Academic Research in Business and Social Sciences, 7(8), 2017, pp. 873-887. 